\title{
Quantitative PCR shows propagation of Plasmodiophora brassicae in Swedish long term field trials
}

\author{
Jonsson Anders • Marzec-Schmidt Katarzyna • \\ Börjesson Gunnar • Wallenhammar Ann-Charlotte
}

Accepted: 9 March 2016 / Published online: 31 March 2016

(C) The Author(s) 2016. This article is published with open access at Springerlink.com

\begin{abstract}
Clubroot (Plasmodiophora brassicae) is a serious soil-borne disease in brassica crops world-wide. We report on a time series of soil samples from Swedish long-term fertility trials started in 1957, 1963 and 1966, which were analyzed for the amount of $P$. brassicae DNA. The crop rotations included a brassica crop every 4 or 6 years. All experimental sites with a 4 -year rotation of oilseed rape, except one with calcium carbonate in the soil profile, showed high ( $>1000 \mathrm{fg} \mathrm{DNA} \mathrm{g}^{-1}$ soil) levels of $P$. brassicae DNA after 9,11 and 12 rotations. In contrast, detectable levels ( $>5 \mathrm{fg}$ DNA g ${ }^{-1}$ soil) of $P$. brassicae were found only at one of five sites with a 6-year rotation of spring oilseed rape. In years with high levels of $P$. brassicae DNA, low yield was reported and a subsequent decline in $P$. brassicae DNA in soil was observed. Different NPK (nitrogen/phosphorus/potassium) fertiliser regimes resulted in similar $P$. brassicae DNA levels. The robustness and reliability of the method applied was verified by analyses of soil from individual plots compared with a mixture of plots and by repeated analyses of selected samples, which showed
\end{abstract}

J. Anders $(\square) \cdot$ M.-S. Katarzyna $\cdot$ W. Ann-Charlotte Precision Agriculture and Pedometrics, Department of Soil and Environment, SLU, PO Box 234, SE- 52323 Skara, Sweden e-mail: anders.jonsson@slu.se

B. Gunnar

Plant Nutrition and Soil Biology, Department of Soil and Environment, SLU, PO Box 7014, SE-750 07 Uppsala, Sweden

W. Ann-Charlotte

HS Konsult AB, PO Box 271, SE-701 45 Örebro, Sweden that $P$. brassicae DNA remained stable during dry storage.

Keywords Long-term fertility field trials - Clubroot . Soil samples · Plasmodiophora brassicae · Quantitative $\mathrm{PCR} \cdot \mathrm{qPCR}$

\section{Introduction}

Clubroot in brassica crops, caused by the obligate endoparasite Plasmodiophora brassicae (Woronin), is recognised as a serious soil-borne disease associated with appreciable yield losses (Wallenhammar 1998; Strelkov and Hwang 2014). It is one of the economically most important diseases of cruciferous crops now found throughout oilseed rape and vegetable brassica growing areas world-wide (Dixon 2009a, 2014). Outbreaks of clubroot have been continuously reported in recent years in winter oilseed rape districts in southern Sweden and more frequently in oilseed rape fields in central Sweden, where production of this crop ceased temporarily due to clubroot 25 years ago (Wallenhammar et al. 2014). The survival structure, resting spores, are produced in large numbers inside infected roots can persist in the soil for up to 17 years (Wallenhammar 1996).

In the early $1950 \mathrm{~s}$, long-term soil fertility trials were established in Sweden to study the influence of mineral fertiliser on long-term productivity compared with the existing regime of circulating plant nutrients in manure (Carlgren and Mattsson 2001). Field experiments were established in the 1950s-1960s in different parts of the 
country and comprised two crop rotations; one including a brassica crop and one including livestock manure, along with 16 combinations of manure and inorganic NPK (nitrogen/phosphorus/potassium) fertiliser. These fertilisers are compared in a 4-year rotation in southern Sweden and a 6-year rotation in central Sweden. In the early 2000s, after 11 and 12 rotations, spring oilseed rape crops were observed to be heavily infected by clubroot at several of the sites. Soil samples have been taken every 4 th and 6 th year in all crop rotations since the start of the experiments and stored dry.

Molecular methods based on polymerase chain reaction (PCR) permit rapid and accurate assessment of soilborne pathogens. Quantification of plant pathogens in soil DNA extracts using real-time quantitative PCR assays has been described for a number of pathogens (e.g. Cullen et al. 2002; Lees et al. 2002; Ratti et al. 2004; Bilodeau et al. 2012). More recently, we developed and validated a real-time quantitative PCR (qPCR) method for detection of $P$. brassicae DNA in naturally and artificially infested soil samples (Wallenhammar et al. 2012). The protocol provides a robust and reliable technique for assessing this disease in soils and for predicting the risk of disease development in various cropping situations, and is now commercially available and used by Swedish farmers.

The objective of the present study was to use qPCR analysis to study changes in the concentration of P. brassicae DNA over time in archived soil samples. The hypotheses were that: (i) P. brassicae DNA concentration, as analysed in archived soil samples, increases to a peak in some years and then decreases in subsequent years; (ii) increasing rate of nitrogen $(\mathrm{N})$ fertiliser decreases clubroot disease severity; and (iii) P. brassicae DNA remains stable during dry storage.

\section{Materials and methods}

Soil samples

The Swedish long-term soil fertility trials were initiated in 1957, 1963 and 1966 by the Department of Plant Nutrition at the Swedish University of Agricultural Sciences and are still ongoing. A complete description of the experimental sites and plans is given by Carlgren and Mattsson (2001). In brief, the 4-year rotation initially included barley (Hordeum vulgare), white mustard (Sinapsis alba), winter wheat (Triticum aestivum) and sugar beet (Beta vulgaris var. altissima). White mustard was replaced by spring oilseed rape (Brassica napus L) in 1986. The 6-year rotation comprises barley, oats (Avena sativa), white mustard/oilseed rape, winter wheat, oats and winter wheat.

The initial soil characteristics (Table 1) were analysed at the laboratory of the Department of Soil and Environment, SLU, Uppsala (Egnér et al. 1960) and these samples were then stored dry at room temperature (Table 1). In 1981 and 1996, lime was applied at any of the experimental sites with a $\mathrm{pH}$ value $<6.1$ (Fig. 1).

Soil was sampled each 4 th or 6 th year after harvest of the winter wheat crop following the brassica crop. The long-term fertility trials comprise several treatments and thus have only two replicates at each site (Carlgren and Mattsson 2001). To further reduce the experimental costs, the replicates are often bulked to one general sample. During selected years, however, all replicates $(n=2)$ were sampled and stored.

Samples from a treatment with annual application of $100 \mathrm{~kg} \mathrm{~N}, 15 \mathrm{~kg} \mathrm{P}$ and $40 \mathrm{~kg} \mathrm{~K} \mathrm{ha}^{-1}$ were chosen for DNA analysis. For the Ekebo site (M5), samples were also analysed from plots fertilised each year with: (i) $0 \mathrm{~kg} \mathrm{~N}, \mathrm{P}$ and K ; (ii) $150 \mathrm{~kg} \mathrm{~N}, 0 \mathrm{~kg} \mathrm{P}$ and $0 \mathrm{~kg} \mathrm{~K}^{-1}$; (iii) $0 \mathrm{~kg} \mathrm{~N}, 45 \mathrm{~kg} \mathrm{P}$ and $120 \mathrm{~kg} \mathrm{~K} \mathrm{ha}^{-1}$; and (iv) $150 \mathrm{~kg} \mathrm{~N}, 45 \mathrm{~kg} \mathrm{P}$ and $120 \mathrm{~kg} \mathrm{~K} \mathrm{ha}{ }^{-1}$. Soils sampled in 2007 were chosen for the first round of analyses to get an indication of P. brassicae DNA concentration. This was followed by analysis of earlier and later samples in the time series showing presence of $\mathrm{P}$. brassicae DNA.

\section{DNA extraction and qPCR}

The protocol developed by Wallenhammar et al. (2012) was used and qPCR analysis was performed in four replicates using the 7300 Real Time PCR System (Applied Biosystems, Foster City, United States). The amount of pathogen DNA was quantified using a standard curve generated by including reactions containing different amounts of a plasmid carrying the $P$. brassicae target sequence.

\section{Influence of storage on P. brassicae DNA}

The samples investigated in this study had been stored dry at room temperature for some years. An important issue was thus possible decomposition of $P$. brassicae DNA during storage. The first analysis using the protocol (Wallenhammar et al. 2012) was performed in 2006 
Table 1 Initial characteristics of the soils at the 10 Swedish long-term fertility experiment sites (1957-1966) and pH (aq) measured in 1995 and 2007

\begin{tabular}{|c|c|c|c|c|c|c|c|c|c|c|c|}
\hline Code & $\begin{array}{l}\text { Site } \\
\text { Name }\end{array}$ & Coordinates & $\begin{array}{l}\text { Org. } \\
\text { carbon \% }\end{array}$ & $\begin{array}{l}\text { Clay } \\
\%\end{array}$ & $\begin{array}{l}\text { P-AL } \\
\text { mg } 100 \mathrm{~g}^{-1}\end{array}$ & $\begin{array}{l}\text { P-HCL } \\
\text { mg } 100 \mathrm{~g}^{-1}\end{array}$ & $\begin{array}{l}\mathrm{K}-\mathrm{AL} \\
\mathrm{mg} 100 \mathrm{~g}^{-1}\end{array}$ & $\begin{array}{l}\text { K-HCL } \\
\mathrm{mg} 100 \mathrm{~g}^{-1}\end{array}$ & $\begin{array}{l}\mathrm{pH}(\mathrm{aq}) \\
1957\end{array}$ & 1995 & 2007 \\
\hline M1 & Fjärdingslöv & $54^{\circ} 24^{\prime} \mathrm{N}, 13^{\circ} 14^{\prime} \mathrm{E}$ & 1.4 & 17 & 3.3 & 26 & 4.2 & 62 & 7.5 & 7.1 & 7.1 \\
\hline M2 & Orup & $55^{\circ} 49^{\prime} \mathrm{N}, 13^{\circ} 30^{\prime} \mathrm{E}$ & 2.4 & 13 & 2.4 & 53 & 3.8 & 47 & 6.2 & 6.0 & 6.1 \\
\hline M4 & Örja & $55^{\circ} 53^{\prime} \mathrm{N}, 12^{\circ} 52^{\prime} \mathrm{E}$ & 1.1 & 15 & 5.9 & 36 & 8.0 & 115 & 7.2 & 7.2 & 6.6 \\
\hline M5 & Ugglarp & $55^{\circ} 38^{\prime} \mathrm{N}, 13^{\circ} 25^{\prime} \mathrm{E}$ & 1.5 & 8 & 4.1 & 38 & 4.1 & 36 & 6.6 & 5.7 & 6.0 \\
\hline M6 & Ekebo & $55^{\circ} 59^{\prime} \mathrm{N}, 12^{\circ} 52^{\prime} \mathrm{E}$ & 3.1 & 14 & 6.7 & 37 & 5.4 & 56 & 6.8 & 6.1 & 6.1 \\
\hline E9 & Högåsa & $58^{\circ} 30^{\prime} \mathrm{N}, 13^{\circ} 14^{\prime} \mathrm{E}$ & 2.4 & 10 & 4.4 & 33 & 10.7 & 43 & $5.9^{1}$ & 6.0 & 6.7 \\
\hline E10 & Vreta Kloster & $58^{\circ} 29^{\prime} \mathrm{N}, 13^{\circ} 08^{\prime} \mathrm{E}$ & 2.1 & 50 & 6.7 & 41 & 19.4 & 368 & $6.7^{1}$ & 6.8 & 7.0 \\
\hline R94 & Bjertorp & $58^{\circ} 14^{\prime} \mathrm{N}, 13^{\circ} 08^{\prime} \mathrm{E}$ & 2.2 & 30 & 4.6 & 38 & 12.4 & 242 & $6.4^{1}$ & 6.1 & 6.5 \\
\hline $\mathrm{C} 7$ & Kungsängen & $59^{\circ} 50^{\prime} \mathrm{N}, 17^{\circ} 40^{\prime} \mathrm{E}$ & 2.1 & 56 & 3.7 & 56 & 14.0 & 440 & $7.1^{2}$ & $6.4^{3}$ & $6.4^{4}$ \\
\hline $\mathrm{C} 8$ & Fors & $60^{\circ} 20^{\prime} \mathrm{N}, 17^{\circ} 29^{\prime} \mathrm{E}$ & 2.2 & 18 & 10.6 & 73 & 9.0 & 252 & $7.7^{2}$ & $7.5^{3}$ & $7.6^{4}$ \\
\hline
\end{tabular}

${ }^{\mathrm{a}}$ Application of lime: $1 \mathrm{t} \mathrm{ha}^{-1} \mathrm{CaO}$ applied in 1981 and $2 \mathrm{tha}^{-1} \mathrm{CaO}$ in 1996 at sites M2, M5 and M6. $2 \mathrm{tha}^{-1} \mathrm{CaO}$ were applied in 1981 at sites M1 and M4. $3 \mathrm{t} \mathrm{ha}^{-1} \mathrm{CaO}$ were applied at site R94 in 2000

${ }^{\mathrm{b}}$ The experiment started in 1966

${ }^{\mathrm{c}}$ The experiment started in 1963

${ }^{\mathrm{d}}$ Values from 1993

${ }^{\mathrm{e}}$ Values from 2005

and those samples are stored dry in the soil bank at the Swedish University of Agricultural Sciences, Skara. Five of these samples were selected for repeated analyses, in 2012 and 2014.

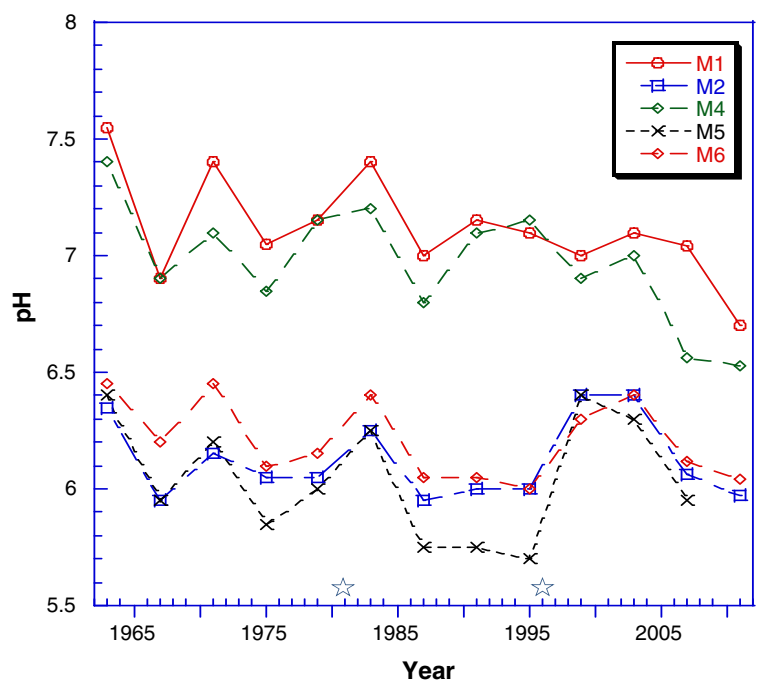

Fig. 1 Changes in soil $\mathrm{pH}$ in the Swedish long-term fertility experiments at sites M1-M6. $\mathcal{W}$ Application of lime: $1 \mathrm{t}$ ha-1 $\mathrm{CaO}$ applied in 1981 and $2 \mathrm{t}$ ha- $1 \mathrm{CaO}$ in 1996 at sites M2, M5 and M6. 2 tha- $1 \mathrm{CaO}$ applied in 1981 at sites M1 and M4
Statistical analysis

The influence of the time of storage on the P. brassicae DNA concentration was analysed using one-way ANOVA and Fisher LSD test with $P=0.05$ significance limit. Statistical analysis was made using the STATISTICA 12 software (StatSoft Inc.)

\section{Results}

Plasmodiophora brassicae DNA was found in soil sampled in 2007 at four of five experimental sites in the 4year rotation (Table 2) and at one of five experimental sites in the 6-year rotation (Table 3). The highest amounts of $P$. brassicae DNA were found in 2007 in the 4-year rotation at experimental sites in southern Sweden. In the 6-year rotation, a level of $P$. brassicae DNA exceeding the quantification limit (i.e. $>5 \mathrm{fg} \mathrm{g}^{-1}$ soil) was observed only at one site, Bjertorp (R 94). Furthermore, when analysing samples from 2013 in the 6-year rotation, $P$. brassicae DNA was detected only at this same experimental site (Table 3).

The analysis of samples from 1971 onwards revealed a change in the level of $P$. brassicae DNA in the 4-year rotation at all experimental sites except Fjärdringslöv 
Table 2 Plasmodiophora brassicae plasmid DNA ( $\mathrm{fg} \mathrm{g}^{-1}$ soil) and relative standard deviation (\%) in archived soil samples collected in the Swedish long-term field fertility experiments (sites M1, M2, M4, M5, M6 and R94) 1971-2011

\begin{tabular}{|c|c|c|c|c|c|c|}
\hline Year & $\begin{array}{l}\text { M1 } \\
\text { Fjärdingslöv }\end{array}$ & $\begin{array}{l}\text { M2 } \\
\text { Orup }\end{array}$ & $\begin{array}{l}\text { M4 } \\
\text { Örja }\end{array}$ & $\begin{array}{l}\text { M5 } \\
\text { Ugglarp }\end{array}$ & $\begin{array}{l}\text { M6 } \\
\text { Ekebo }\end{array}$ & $\begin{array}{l}\text { R94 } \\
\text { Bjertorp }^{c}\end{array}$ \\
\hline 1971 & $<5$ & $<5$ & $\mathrm{n} \cdot \mathrm{d}^{\mathrm{a}}$ & $<5$ & $<5$ & $<5^{\mathrm{c}}$ \\
\hline 1975 & $<5$ & $<5$ & $\mathrm{n} \cdot \mathrm{d}^{\mathrm{a}}$ & $\mathrm{n} \cdot \mathrm{d}^{\mathrm{a}}$ & $<5$ & \\
\hline 1979 & $\mathrm{n} . \mathrm{d}^{\mathrm{a}}$ & $<5$ & $<5$ & $<5$ & $5 \pm 40$ & $<5^{\mathrm{c}}$ \\
\hline 1983 & $\mathrm{n} \cdot \mathrm{d}^{\mathrm{a}}$ & $<5$ & $<5$ & $<5$ & $5 \pm 40$ & \\
\hline 1987 & $\mathrm{n} \cdot \mathrm{d}^{\mathrm{a}}$ & $<5$ & $<5$ & $<5$ & $7 \pm 14$ & $<5^{\mathrm{c}}$ \\
\hline 1991 & $\mathrm{n} \cdot \mathrm{d}^{\mathrm{a}}$ & $8684 \pm 44$ & $<5$ & $372 \pm 33$ & $1110 \pm 15$ & $<5^{\mathrm{c}}$ \\
\hline 1995 & $\mathrm{n} \cdot \mathrm{d}^{\mathrm{a}}$ & $5 \pm 6$ & $<5$ & $5 \pm 2$ & $5210 \pm 4$ & \\
\hline 1999 & $<5$ & $38,786 \pm 3$ & $9 \pm 33$ & $3063 \pm 42$ & $14,182 \pm 14$ & $20^{\mathrm{c}} \pm 20$ \\
\hline 2003 & $<5$ & $7907 \pm 6$ & $1200 \pm 26$ & $1370 \pm 80$ & $19,753 \pm 4$ & \\
\hline 2007 & $<5$ & $635 \pm 48$ & $138 \pm 108$ & $338 \pm 8$ & $1433 \pm 61$ & $252^{c} \pm 24$ \\
\hline 2011 & $<5$ & $80 \pm 9$ & $5 \pm 40$ & $\mathrm{n} \cdot \mathrm{a}^{\mathrm{b}}$ & $37 \pm 5$ & $1012 \pm 130$ \\
\hline
\end{tabular}

${ }^{\mathrm{a}}$ n.d no detection, ${ }^{\mathrm{b}}$ n.a not analysed; field trial stopped in 2010, ${ }^{\mathrm{c}}$ Bjertorp 6-year rotation sampled in 1971, 1978, 1985, 1992, 2001, 2007 and 2013

(M1) (Table 2). The increase in P. brassicae DNA peaked at four of the experimental sites in the soil samples from 1999 and 2003. In general, there was an increase in the level of $P$. brassicae DNA of more than 1000 -fold at the peak level and it differed by approximately 10-fold between sites M2 and M6 and sites M4 and M5. Interestingly, in 1991 the amount of pathogen DNA at sites M2, M5 and M6 was already high (range 372-8684 fg plasmid DNA g ${ }^{-1}$ soil). Similar patterns of change in $P$. brassicae DNA levels were observed in samples from treatments under different fertilisation regimes (Table 4).

At site M6, quantifiable levels of $P$. brassicae DNA were found in the samples from 1979 and at sites M2 and M5 in the samples from 1991. High levels of P. brassicae DNA were found in soil samples from 1999 and 2003 at M2, M5 and M6. Moreover, in 2002 low yield was reported at M2 (1450 kg ha $\left.{ }^{-1}\right)$, M4
(1180 kg ha $\left.\mathrm{kg}^{-1}\right)$ M5 (1360 $\left.\mathrm{kg} \mathrm{ha}^{-1}\right)$ and M6 $\left(1050 \mathrm{~kg} \mathrm{ha}^{-1}\right)$, whereas yield at M1 was higher, $2038 \mathrm{~kg} \mathrm{ha}^{-1}$ (Table 5).

TThe high levels of $P$. brassicae DNA in samples from 2003 were followed by a substantial decrease (75$93 \%$ ) at all 4-year rotation sites sampled in 2007 and similar decreases (88-96\%) in the following 4 years to 2011 (Table 2). Similar patterns of change in $P$. brassicae DNA levels were observed in samples from treatments with different fertilisation regimes (Table 4).

To test the effect of mixing dried samples on quantification, the available replicates $(n=2)$ from experimental sites M2 (1991, 1999 and 2003) and M6 (1971, 1975 , 1999) were analysed (Table 5). This test of accuracy was performed on two separate occasions for the two plot samples and the bulked samples. At site M2, yield in the two replicate plots was similar despite differences in P. brassicae DNA between these replicates (Table 5).

Table 3 Prevalence of $P$. brassicae DNA in soil (DNA $\mathrm{fg} \mathrm{g}^{-1}$ soil) in the Swedish long-term fertility trials with oilseed crops in the crop rotation. 6th year of rotation, sampled 2007 and 2013

\begin{tabular}{lllll}
\hline Code & Site Name & Coordinates & P. brassicae DNA (fg g ${ }^{-1}$ soil) 2007 & n.d \\
\hline E9 & Högåsa & $58^{\circ} 30^{\prime} \mathrm{N}, 13^{\circ} 14^{\prime} \mathrm{E}$ & n.d & n.d \\
E10 & Vreta Kloster & $58^{\circ} 29^{\prime} \mathrm{N}, 13^{\circ} 08^{\prime} \mathrm{E}$ & n.d & $1012 \pm 130$ \\
R94 & Bjertorp & $58^{\circ} 14^{\prime} \mathrm{N}, 13^{\circ} 08^{\prime} \mathrm{E}$ & $252 \pm 24$ & n.d \\
C7 & Kungsängen & $59^{\circ} 50^{\prime} \mathrm{N}, 17^{\circ} 40^{\prime} \mathrm{E}$ & n.d & n.d \\
C8 & Fors & $60^{\circ} 20^{\prime} \mathrm{N}, 17^{\circ} 29^{\prime} \mathrm{E}$ & n.d & \\
\hline
\end{tabular}

n.d no detection of P. brassicae plasmid DNA 
Table 4 Plasmodiophora brassicae plasmid DNA ( $\mathrm{fg} \mathrm{g}^{-1}$ soil) in archived soil samples collected in the Swedish long-term fertility experiment at Ekebo (site M6), 1987-2011, from treatments with different fertilisation regimes: No addition of NPK; $0 \mathrm{~kg} \mathrm{~N}, 45 \mathrm{~kg}$ $\mathrm{P}$ and $80 \mathrm{~kg} \mathrm{ha}^{-1}$ year $^{-1} ; 150 \mathrm{~kg} \mathrm{~N}$ ha $^{-1}$ year $^{-1}, 0 \mathrm{~kg} \mathrm{P}$; and $150 \mathrm{~kg} \mathrm{~N}, 45 \mathrm{~kg} \mathrm{P}, 80 \mathrm{~kg} \mathrm{~K} \mathrm{ha}^{-1}$ year $^{-1}$. Relative standard deviation, $\pm \%$

\begin{tabular}{lllll}
\hline Year & Fertiliser & $\left(\mathrm{kg} \mathrm{ha}^{-1}\right.$ year $\left.^{-1}\right)$ & & \\
& N 0 & N 0 & N 150 & N 150 \\
& P 0 & P 45 & P 0 & P 45 \\
& K 0 & K 80 & K 0 & K 80 \\
\hline 1987 & $<5$ & $<5$ & $10 \pm 50$ & $2665 \pm 10$ \\
1991 & n.d. & $<5$ & $<5$ & $<5$ \\
1995 & $72 \pm 0$ & $216 \pm 19$ & $2737 \pm 23$ & $7078 \pm 7$ \\
1999 & $<5$ & $20,217 \pm 35$ & $<5$ & $36,663 \pm 11$ \\
2003 & $67,731 \pm 10$ & $323 \pm 3$ & $33,838 \pm 13$ & $21,099 \pm 9$ \\
2007 & $33 \pm 27$ & $112 \pm 17$ & $25 \pm 12$ & $\mathrm{~m} . \mathrm{s}^{\mathrm{a}}$ \\
2011 & $<5$ & $16 \pm 25$ & $<5$ & $20 \pm 5$ \\
\hline
\end{tabular}

${ }^{a}$ missing value

Analysis of the influence of storage time on detected amount of $P$. brassicae DNA in 2012 and 2014 in five samples first analysed in 2006 revealed that the amount had changed significantly in two samples during 6 or 8 years of storage (Table 6).

\section{Discussion}

The qPCR method provides new possibilities to analyse the presence of pathogen DNA in archived samples and to re-evaluate observations in long-term field experiments. We examined clubroot disease development over time using a qPCR assay on archived soil samples from two series of crop rotation experiments with brassica crops running for 42 years. The results confirmed the first hypothesis, that $P$. brassicae DNA concentration in soil increases, reaches a peak, and then decreases as a consequence of successful infection of OSR crops, club formation followed by degradation of spores in the soil. The oilseed crops in the 4-year rotation were heavily infected with $P$. brassicae, recorded by field personnel as high number of plants showing clubroot disease symptoms, at two experimental sites (M6 and M2) in 2002. This outbreak of clubroot was accompanied by an increase in P. brassicae DNA in soil, followed by a rapid decline in the P. brassicae DNA level (Table 2).

The qPCR results also showed that $P$. brassicae inoculum was already present in amounts $\left(5 \mathrm{fg} \mathrm{g}^{-1}\right)$ corresponding to more than 3000 spores per g soil at three of five sites in the 4-year crop rotation in 1991, 12 years (or three Brassica crops) before considerable yield losses were observed in 2002 at sites M2 and M6 were attributed to clubroot (Table 5). This shows the significance of early detection of the pathogen and of analysing the level of $P$. brassicae DNA before deciding on the frequency of brassica crops in a specific field.

At experimental sites M2 and M6, the amount of P. brassicae DNA reached a peak in 1999, so severe clubroot infection is likely to have occurred in 1998, after a spring oilseed crop had been grown for the 11th time. The substantial increase in P. brassicae DNA was probably a consequence of clubroot occurrence already in 1990. There were considerable yield reductions in 2002 at M6 and M2, but at M2 also in 1998. In 2000, the yield at site M1, with no detection of $P$. brassica DNA, was $2038 \mathrm{~kg}$ ha, i.e. $30 \%$ and $48 \%$ higher than at sites M2 and M6, respectively. Clubroot as the cause of yield loss was first confirmed at site M6 in 2002, indicating the problem for growers of detecting clubroot in field crops without systematic assessment. As pointed out in the previous study (Wallenhammar et al. 2012), there is a risk of $>10 \%$ crop losses in susceptible crops with P. brassicae DNA concentrations in soil ranging from 5 to $200 \mathrm{fg}$ plasmid DNA g ${ }^{-1}$ soil (corresponding to 3000 to 130000 spores $^{-1}$ soil). As a consequence of significant yield losses in 2002, spring oilseed rape was replaced in the experimental rotation with an oat crop.

Patchy development of clubroot and the risk of infestation between plots might have affected the results obtained in this study in various ways, since the samples were not handled in the sterile way recommended in Wallenhammar et al. (2012). Patchiness has been observed between plots in the experiment (Table 5). The similar pattern of increase in pathogen DNA at sites M2, M4, M5 and M6 and the similar amount of P. brassicae DNA in the plotwise observations support the validity of the results. Results from the analysis before and after bulking of plotwise soil samples (Table 5), together with repeated analyses of dried samples 2006-2014 (Table 6), further confirmed that the observed levels are relevant and in accordance with the third hypothesis, i.e. that the concentration of P. brassicae DNA has remained stable enough over time during dry storage, and our observation of an important pattern in the epidemiology of $P$. brassicae. The observed reduction of $P$. brassicae DNA in stored samples was significant in some samples (Table 6) but not considered of sufficient 
Table 5 Plasmodiophora brassicae plasmid DNA ( $\mathrm{fg} \mathrm{g}^{-1}$ soil) in archived soil samples from the Swedish long-term fertility trials at sites M2 (Orup) and M6 (Ekebo). A 50/50 (\% w/w) mixture of duplicate soil samples from plots 44 and 58 was compared with individual samples from these plots. The calculated average for the $50 / 50(\% w / w)$ mix is also shown. In addition, plotwise yield data are presented for site $\mathrm{M} 1$ (Fjärdringslöv). OSR = oilseed rape

Site \& Year Plot sample Results of analysis Calculated average, $\left(\mathrm{fg} \mathrm{g}^{-1}\right.$ soil $)$ Harvest year Yield of OSR kg ha ${ }^{-1}$ Yield OSR kg ha $^{-1}$ (fg $\mathrm{g}^{-1}$ soil) for the mix $50 / 50(\%)$

M2 Orup

M1 Fjärd.

1991

1999

$\begin{array}{ll}44 & 2235 \\ 58 & 14,921 \\ \text { Mix 44/58 } & 8684\end{array}$

$\begin{array}{lll}1990 & 1442 & 1743 \\ & 1517 & 1796\end{array}$

$\begin{array}{lll}44 & 772 & \\ 58 & 88,350 & \\ \text { Mix 44/58 } & 38,786 & 43,561(112 \%)\end{array}$

2003

$\begin{array}{ll}44 & 3534 \\ 58 & 17,377 \\ \text { Mix } 44 / 58 & 7907\end{array}$

$10,455(132 \%)$

2002

1434

2067

1447

2006

M6 Ekebo

$\begin{array}{ll} & \\ 44 & <5 \\ 58 & <5 \\ \text { Mix } 44 / 58 & <5\end{array}$

1975

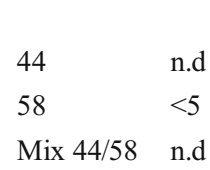

$<5(-)$

$\begin{array}{ll}44 & 23,997 \\ 58 & 16,674\end{array}$

Mix 44/58 14,182

20,335 (143\%)

2003

\begin{tabular}{|c|}
\hline 44 \\
\hline 58 \\
\hline
\end{tabular}

$<5(-)$

1999

Mix 44/58 19,753

$1970 \quad 1970 \quad 2080$

$1974 \quad 1790$

$\begin{array}{lll}1998 & 1880 & 2376 \\ 1706 & 1820\end{array}$

$2002 \quad 1030 \quad 2067$

10512006

magnitude to affect the general interpretation of the results. A previous report that DNA can be extracted from non-viable microorganisms after 140 years of storage of air-dried soil samples (Hirsch et al. 2013) confirms the conclusions.

The amount of $P$. brassicae DNA declined significantly in the 4 years following the peak, with a reduction of approx. 90-95\% for each consecutive 4-year period. Similarly, Peng et al. (2013) reported a $90 \%$ reduction in spores with a 2-year break. The half-life of resting spores is estimated to be 3.6 years in central Sweden (Wallenhammar 1996) and 4.4 years in central Alberta (Hwang et al. 2013). In the present study, the half-life of $P$. brassicae DNA was approx. 1 year during the 8 years. Despite this rapid decay, the amount $\left(>20.000 \mathrm{fg} \mathrm{g}^{-1}\right)$ observed in soil samples 1 year after the spring oilseed crop was equivalent to 4 million spores $\mathrm{g}^{-1}$ soil, so with a reduction of $90 \%$ every 4 years, it would still take 16 years to reach a level of less than 1000 spores $\mathrm{g}^{-1}$ soil. The rapid decline in $P$. brassicae DNA raises 
Table 6 Plasmodiophora brassicae plasmid DNA ( $\mathrm{fg} \mathrm{g}^{-1}$ soil) in archived soil samples collected and analysed in 2006 and in analyses repeated in 2012 and 2014

\begin{tabular}{llllll}
\hline Year & \multicolumn{5}{l}{ Soil sample } \\
\cline { 2 - 6 } & No:92 & No:300 & No:334 & No:96 & No:312 \\
\hline 2006 & $4,7^{\mathrm{a}}$ & $3,9^{\mathrm{a}}$ & $175^{\mathrm{a}}$ & $341^{\mathrm{a}}$ & $1108^{\mathrm{a}}$ \\
2012 & $4,3^{\mathrm{a}}$ & $5.0^{\mathrm{a}}$ & $22^{\mathrm{b}}$ & $268^{\mathrm{a}}$ & $936^{\mathrm{ab}}$ \\
2014 & $3,0^{\mathrm{a}}$ & $<5$ & $22^{\mathrm{b}}$ & $282^{\mathrm{a}}$ & $671^{\mathrm{b}}$ \\
\hline
\end{tabular}

${ }^{a}$ Different letters indicate statistically significant differences

questions about the condition and vitality of the surviving spores and indicates a need for more information about the mechanism causing suppressiveness and decline (Donald and Porter 2009).

Suppression of clubroot development by addition of different nitrogen fertilisers was observed by Nilsson (2014) in growth chamber experiments and was also reported by Dixon $(2009 b, c)$. In the present study, however, the pattern observed for changes in P. brassicae plasmid DNA was similar in all samples from the treatments at Ekebo (M5), where increasing amounts of $\mathrm{N}$ fertiliser were applied (Table 4). This contradicts the second hypothesis, that increasing rate of $\mathrm{N}$ decreases clubroot severity.

The results showed that the amount of spores found after a severe outbreak is 100-1000 times higher than that reported to be needed for infection (Diedrichsen et al. 2009; Tsushima et al. 2010). The high levels of $P$. brassicae DNA found in the archived soil samples indicate great potential for transmission of $P$. brassicae inoculum between fields via infected soil carried by farm equipment (Cao et al. 2009; Gossen et al. 2014; Strelkov and Hwang 2014). Wind erosion is another important transmission pathway, as substantial amounts of inoculum are present in wind-blown dust from infested fields (Rennie et al. 2015).

Soil $\mathrm{pH}$ and calcium concentration are important characteristics for interpreting the development of clubroot (Webster and Dixon 1991). The soil at site M1, where P. brassicae DNA was barely detected, has a sandy loam texture, with increasing clay and calcium carbonate concentration to $100 \mathrm{~cm}$ depth and a $\mathrm{pH}$ value of 8.0 at 50 $100 \mathrm{~cm}$ depth (Carlgren and Mattsson 2001). These characteristics most likely supported the disease suppressive ability of that soil. The soil at site M4, where $P$. brassicae DNA increased at a lower rate, is a sandy clay loam with low calcium carbonate concentration throughout the profile, whereas the soil at the most disease-conducive experimental site, M6, lacks calcium carbonate and has a $\mathrm{pH}$ value of 5.7 at $50-100 \mathrm{~cm}$ depth (Carlgren and Mattsson 2001). The $\mathrm{pH}$ at sites M1 and M4 showed less variability than at sites M2, M5 and M6 and, moreover, lime has been applied twice at these sites, compared with once at M1 and M4 (Fig. 1). The properties of soils with a natural content of calcium carbonate need to be further studied. For example, Webster and Dixon (1991) studied the relationships between P. brassicae, calcium ions and $\mathrm{pH}$ and showed that increased calcium content reduced the number and severity of infections, depending on inoculum pressure. These findings were confirmed and extended by Dixon and Page (1998). Application of lime is regarded as a positive clubroot suppressive measure that should be carried out regularly in oilseed rape production. The correlation between $\mathrm{pH}$ value and disease incidence is, however, often found to be weak (Wallenhammar 1996; Strelkov et al. 2007; Gossen et al. 2013) and should probably be evaluated with regard to soil calcium concentration.

In conclusion, this qPCR analysis of stored samples from the Swedish long-term fertility trials revealed a substantial increase in P. brassicae DNA in soil during the years preceding destructive $P$. brassicae infection, followed by a rapid decline in subsequent years. The results confirmed the risk of clubroot proliferation associated with short-time rotations of Brassica crops. The low level of $P$. brassicae DNA recorded in the 6-year rotation indicates that a rotation with a period of 5 years between brassica crops is one of the most efficient measures in integrated control of clubroot (Wallenhammar 1999). Since the profitability of oilseed rape cropping is attractive, much shorter rotations are used in practice (Wallenhammar et al. 2014). For example, in southern Sweden a crop rotation with 3 years between brassica crops is common and even shorter intervals have been reported, especially in Canada (Peng et al. 2014). On the Canadian prairies, a break of 3 years in combination with resistant cultivars was suggested by Peng et al. (2014) as a strategy to manage fields infected with clubroot. Our studies in the Swedish long-term fertility trials indicate that a 3-year break between brassica crops is too short and that general recommendations should be replaced by field-specific recommendations based on analysis of $P$. brassicae DNA in soil. 
Acknowledgments The authors wish to thank the Faculty of Natural Resources and Agriculture (NL), Swedish Agricultural University (SLU), the Swedish Farmers' Foundation for Agricultural Research, the Farmers' Cooperation Foundations (VL and SL) and the Foundation for Swedish Oil Plant Research for financial support. We would also like to thank Ms. Charlotta Almquist, Ms. Åsa Fransson and Ms. Ellen Alexandersson for technical assistance.

Open Access This article is distributed under the terms of the Creative Commons Attribution 4.0 International License (http:// creativecommons.org/licenses/by/4.0/), which permits unrestricted use, distribution, and reproduction in any medium, provided you give appropriate credit to the original author(s) and the source, provide a link to the Creative Commons license, and indicate if changes were made.

\section{References}

Bilodeau, G., Koike, S., Uribe, P., \& Martin, F. (2012). Development of an assay for rapid detection and quantification of Verticillium dahliae in soil. Phytopathology, 102, 331-343.

Cao, T., Manolii, V., Hwang, S.-F., Howard, R. J., \& Strelkov, S. E. (2009). Virulence and spread of Plasmodiophora brassicae (clubroot) in Alberta, Canada. Canadian Journal of Plant Pathology, 31, 321-329.

Carlgren, K., \& Mattsson, L. (2001). Swedish soil fertility experiments. Acta Agriculturae Scandinavica, Section B-Plant Soil Science, 51(2), 49-76.

Cullen, D. V., Lees, A. K., Toth, I. K., \& Duncan, J. M. (2002). Detection of Colletotrichum coccodes from oil and potato tubers by conventional and quantitative real-time PCR. Plant Pathology, 51, 281-292.

Diedrichsen, E., Frauen, M., Linders, E. G. A., Hatakeyama, K., \& Hirari, M. (2009). Status and perspectives of clubroot resistance breeding in crucifer crops. Journal of Plant Growth Regulation, 28, 265-281.

Dixon, G. R. (2009a). The occurrence and economic impact of Plasmodiophora brassicae and clubroot disease. Journal of Plant Growth Regulation, 28, 194-202.

Dixon, G. R. (2009b). Husbandry-the sustainable means of controlling soil borne pathogens: a synoptic review. Acta Horticulturae, 817, 233-242.

Dixon, G. R. (2009c). Plasmodiophora brassicae in its environment. Journal of Plant Growth Regulation, 28, 289-303.

Dixon, G. R. (2014). Clubroot (Plasmodiophora brassicae Woronin)- an agricultural and biological challenge worldwide. Canadian Journal of Plant Pathology, 36(S1), 518.

Dixon, G. R., \& Page, L. (1998). Calcium and nitrogen eliciting alterations to growth and reproduction of Plasmodiophora brassicae (clubroot). Acta Horticuturae, 459, 343-349.

Donald, C., \& Porter, I. (2009). Integrated control of clubroot. Journal of Plant Growth Regulation, 28, 289-303.

Egnér, H., Riehm, H., \& Domingo, W. R. (1960). Untersuchung über die chemische Bodenanalyse als Grundlage für die Berurteilung des Nährstoffzustandes der Böden. The Annals of Royal Agricultural College of Sweden, 26, 199-215 (in German).

Gossen, B. D., Kasinathan, H., Cao, T., Manolii, V. P., Strelkov, S. E., Hwang, S.-F., \& McDonald, M. R. (2013). Interaction of $\mathrm{pH}$ and temperature affect infection and symptom development of Plasmodiophora brassicae in canola. Canadian Journal of Plant Pathology, 35, 294-303.

Gossen, B. D., Dehora, A., Peng, G., Hwang, S.-F., \& McDonald, M. R. (2014). Effect of environmental parameters on clubroot development and the risk of pathogen spread. Canadian Journal of Plant Pathology, 36(S1), 37-48.

Hirsch, P. R., Mauchline, T., \& Clark, I. M. (2013). Cultureindependent molecular approaches to microbial ecology in soil and the rhizosphere. In F. J. de Bruijn (Ed.), Molecular ecology of the rhizosphere (pp. 45-55). Hoboken: Wiley.

Hwang, S. F., Ahmed, H. U., Zhou, Q., Rashi, A., \& Strelkov, S. E. (2013). Effect of susceptible and resistant canola plants on Plasmodiophora brassicae resting spore populations in the soil. Plant Pathology, 62, 404-412.

Lees, A. K., Cullen, D. W., \& Sullivan, L. (2002). Development of conventional and quantitative real-time PCR assay for Phytophthora infestans and its applicability to leaf, tuber and soil samples. Plant Pathology, 61, 867-876.

Nilsson, M. (2014). Effekt av olika kvävegödselmedel på utvecklingen av klumprotsjuka i salladskål (Brassica rapa ssp. pekinensis). MSc-thesis at Department of Soil and Environment, SLU, 2014:07, Uppsala 2014. http://stud. epsilon.slu.se/7124/.

Peng, G., Pageau, D., Strelkov, S., Lahali, R., Hwang, S. F., \& Adhikari, K. K. C. (2013). Assessment of crop rotation, cultivar resistance and Bacillus subtilis biofungicide for control of clubroot on canola. Acta Horticulturae, 1005, 591598.

Peng, G., Lahlali, R., Hwang, S. F., Pageau, D., Hynes, R. K., McDonald, M. R., Gossen, B. D., \& Strelkov, S. E. (2014). Crop rotation, cultivar resistance and fungicides/ biofungicides for managing clubroot (Plasmodiophora brassicae) on canola. Canadian Journal of Plant Pathology, 36(S1), 99-112.

Ratti, C., Budge, G., \& Ward, L. (2004). Detection and relative quantification od soil-borne cereal mosaic virus (SBCMV) and Polymyx agaraminis in winter wheat using real-time PCR (TaqMan R). Journal of Virological Methods, 122, 95-103.

Rennie, D. C., Holtz, M. D., Turkington, T. K., Leboldus, J. M., Hwang, S.-F., Howard, R. J., \& Strelkow, S. E. (2015). Movement of Plasmodiophora brassicae resting spores in wind blown dust. Canadian Journal of Plant Pathology, 37(2), 188-196.

Strelkov, S. E., \& Hwang, S.-F. (2014). Clubroot in the Canadian canola crop: 10 years into the outbreak. Canadian Journal of Plant Pathology, 36(S1), 27-36.

Strelkov, S. E., Manolii, V. P., Cao, T., Xue, S., \& Hwang, S. F. (2007). Pathotype classification of Plasmodiophora brassicae and its occurrence in Brassica napus in Alberta, Canada. Journal of Phytopathology, 155, 706-712.

Tsushima, S., Murakami, H., Akimoto, T., Katahira, M., Kuroyanagi, Y., \& Shishido, Y. (2010). A practical estimating method of the dose-reponse curve between inoculum density of Plasmidiophora brassicae and disease severity for long- 
term IPM strategies. Japan Agricultural Research Quarterly, 44(4), 383-390.

Wallenhammar, A.-C. (1996). Prevalence of Plasmodiophora brassicae in a spring oilseed rape growing area in central Sweden and factors influencing soil infestation levels. Plant Pathology, 45, 710-719.

Wallenhammar, A.-C. (1998). Observations on yield loss from Plasmodiophora brassicae infections in spring oilseed rape. Zeitschrift fur Pl'flanzenkrankheit und Pflanzenschutz, 105, 1-7.

Wallenhammar, A.-C. (1999). Monitoring and control of Plasmodiophora brassicae in spring oilseed Brassica crops. Uppsala: Swedish University of Agricultural Sciences PhD thesis.
Wallenhammar, A.-C., Almquist, C., Söderström, M., \& Jonsson, A. (2012). In field distribution of Plasmodiophora brassicae measured using quantitative real-time PCR. Plant Pathology, 61, 16-28.

Wallenhammar, A.-C., Almquist, C., Schwelm, A., Roos, J., Marzec-Schmidt, K., Jonsson, A., \& Dixelius, C. (2014). Clubroot, a persistent threat to Swedish oilseed rape production. Canadian Journal of Plant Pathology, 36(S1), 135141.

Webster, M. A., \& Dixon, G. R. (1991). Calcium, pH and inoculum concentrations influencing colonisation by Plasmodiophora brassicae. Mycological Research, 95, 64-73. 